\title{
REGIONAL ORGANIZATION OF RESEARCH IN AUSTRALIA AND SOUTH-EAST ASIA
}

T HE concept of the development of scientific research on a regional basis is one which has long been advocated by Unesco, and followed in the operations of its field science co-operation offices. The South-east Asia Science Co-operation Office has been active in stimulating collaboration and co-operation in a number of scientific fields in its region, and has been responsible for two important meetings-in Bandung in 1959 and in Hong Kong in 1961. Representatives of national research councils in the area met to discuss general problems of organizing scientific research (see Nature, 186, 859, 1960; 194, 626, 1962). More recently, in February 1964, a third meeting was held in Canberra, Australia, for a similar purpose, the local arrangements being made by the Australian Commonwealth Scientific and Industrial Research Organization.

The Canberra meeting enlarged the scope of the earlier meetings, as it included representatives of national research organizations from both South and South-east Asia. Delegates came from Ceylon, China (Taiwan), Hong Kong, Indonesia, India," Israel, Japan, Korea, Malaysia, Nepal, New Zealand, Pakistan, Philippines, Thailand, Viet Nam and Australia. There were also present consultants from India, Indonesia, Japan, the United States, the U.S.S.R. and Australia, and observers from the World Health Organization, the Food and Agriculture Organization, the Pacific Science Association, the PanIndian Ocean Science Association and the South Pacific Commission.

Following the United Nations conference on the "Application of Science and Technology for the Benefit of the Less Developed Areas" (Nature, 197, 1135; 1963) in Geneva in 1963, Unesco made plans to extend considerably its activities in the field of natural science, and the Canberra meeting was looked on as a regional follow-up to the Geneva conference. It was considerably strengthened by the presence of M. Rene Maheu, the director-general of Unesco, for part of the proceedings and a delegation from Unesco headquarters including Prof. V. Kovda, the director of the Natural Sciences Department. Sir Frederick White, chairman of C.S.I.R.O., was elected chairman of the meeting. Prof. Sarwono Prawirohardjo, president of the Indonesian Council of Sciences, was olected rapporteur.

The meeting, which was held in the Australian Academy of Science building, was opened with an address from Senator the Honourable J. G. Gorton, the Australian minister assisting the Prime Minister in education and research. $\mathrm{Mr}$. Gorton referred to the fact that many developing areas could benefit significantly by the application of scientific facts which were already known, so that it was essential for Governments to provide adequate extension services and ensure the supply of trained technicians.

M. Rene Maheu also addressed the meeting and emphasized what he described as the salient features of the Geneva conference: that countries can scarcely hope to obtain economic independence-and political independence without economic independence is little more than a façade-if their own scientific and technical potential remains below a minimum threshold. A far-sighted governmental policy for science will seek two main objectives: to develop scientific and technical potential on one hand, and, on the other, to apply the creative and assimilative capacities of that potential to the cultural, economic and social progress of the country. The purpose of the Canberra meeting was to define fields of application, and methods of formulating and executing such national scientific policies.

The principal sessions of the meeting covered national science policies, relations between science and Government, research and economic development, investment in research, research organization and administration, and regional collaboration in research and training.

Underlying all the discussions was the question raised by M. Maheu: how best to ensure that science plays its most effective part in the processes of economic development. This involves the setting-up of suitable advisory machinery for government. It will vary according to the stage of the political, economic and scientific development of the country concerned, but must bring the possibilities of science to the notice of the economic planners, and also ensure feed-back of economic problems to research groups. Proper organization and management are essential if science is to flourish and to make an effective contribution to development. At the same time it is necessary to plan educational and manpower development and to ensure the availability of trained men, not only to engage in investigation and research, but also to ensure that research results are put to agricultural and industrial use.

As was to be expected, discussion was largely directed towards the role and activities of Unesco in the regions represented at the meeting. It was clear that there was general appreciation of the work which Unesco has been doing in the various countries concermed, though there was by no means an uncritical acceptance of all its policies. The principal help needed from Unesco was towards building up within each country an organization which would enable it to develop internal solutions to its own problems.
G. B. GRESFORD

\section{ASPECTS OF SOIL SCIENCE}

\section{T} HE eighth International Congress of Soil Science was held in Bucharest during August 31-September 9. The official opening of the Congress was held in the Great Hall of the Palace of the Romanian Peoples Republic by President Gheorghe Gheorghiu-Dej. In his speech welcoming the 1,200 delegates, the Romanian President stressed the need for raising the standards of food production in the world. He complimented the International Soil Science Society for its contribution to this vital work, and for the part it played in the development of understanding and peace.

After the necessary business of the Society had been concluded, the programme of scientific papers began with a general session in which the history and progress of the Food and Agriculture Organization/Unesco project for a
World Soil Map were described. Good progress had been made, and hence it was possible for several maps to be exhibited at the Congress. Throughout the nino remaining days of the meeting, more than 700 papers were read to the seven Commissions of the Congress, dealing with soil physics, soil chemistry, soil biology, soil fertility, soil genesis, classification and cartography, soil technology, and soil mineralogy. Abstracts of the papers were made available in English, French and Cerman, and the proceodings of the Congress will be published in the near future.

The papers read in Commission 1 (Soil Physics) dealt, with such diverse topics as the physical relationships between the solid and liquid phases of the soil and the relationship of tillage problems to physical properties. Several papers were devoted to investigations of the? 
movement of water in saturated and unsaturated conditions through the soil. Soil chemists in Commission 2 concerned themselves with fundamental problems of research, and in particular research pertaining to the properties and formation of humus complexes. The importance of chemical change, especially exchangeable cation relationships, associated with soil genesis was also discussed. The investigation of the soil solution assumes even greater importance in the semi-arid areas where salt concentrations are sufficient to affect crop production. The influence of irrigation on saline and alkaline soils was reviewed by delegates from Egypt, Israel, the United States, Spain, Tunis, Hungary, Turkey, the U.S.S.R., and Romania. At the other extreme of the $p H$ scale, the moderation of acid soils and their improvement for agriculture were the subjects of several papers. In a joint session with Commission 4 (Soil Fertility) the problems of the chemistry and biochemistry of phosphorus in the soil and in plant nutrition aroused considerable interest.

Problems involved in the examination of soil micro. and macro-fauna were discussed, and of special interest to the non-specialist in this field was the section dealing with the possibility of control of the activity of soil organisms. The variation of the natural environment within the soil and its repercussions on populations of organisms enables the soil biologists to gauge the effects of modern pesticides on the beneficial inhabitants of the soil. Interactions of soil micro-organisms and higher plants were discussed as well as the nature and effect of bacterial fertilizers.

The role and efficiency of fertilizers were the province of Commission 4, and the influence of soil conditions on nutrient availability to plants was discussed, as was the part played by organic matter in soil fertility. The section of the programme dealing with the efficacy of fertilizers on genetic soil types with different crops under irrigated or non-irrigated conditions provided an interesting link with the work of those concerned with soil classification. Many problems arising from the deficiency of major plant nutrients are now fairly well understood and have been remedied in advanced countries. However, the minute amount of the minor elements necessary has become an important investigation: papers read included reference to boron, zine, molybdenum and sulphur, in various soils.

The most extensive programme was that undertaken by Commission 5 (Soil Genesis, Classification and Cartography). In this section alone more than 160 papers were read. As might be expected, the soils of south-eastern Europe were discussed at some length by delegates from the host country, Romania, and from Hungary and Bulgaria. Other sections were devoted to the origin and genesis of soils of the desert and semi-desert, steppe, mountain and cold regions, tropical, Mediterranean and sub-tropical regions. Progress in soil mapping and cartography was outlined by speakers from many different parts of the world.

Soil technology is never far removed from the fundamental investigations of soil chemistry and physics, and it was no surprise to find that there were joint sessions of Commission 6 with Commissions 1 and 2. Soil erosion is always a danger, particularly in semi-arid lands, and methods for its control have been developed from funda. mental investigations of the physical and chemical conditions of soils. The improvement of eroded land provides the soil scientists with special problems, and on this point papers were read dealing with wind and water erosion and its control in Europe and in North and South America. Other topics in this Commission were the reclamation of saline and alkaline soils under irrigated and non-irrigated conditions; fuctor's regarding the time and amount of irrigation water; and the influence of tillage depth and fertilizer placement on plant rooting.

Delegates to Commission 7 (Soil Mineralogy) were especially concerned with the genesis and changes that occur in the minerals present in soils; methods of identification of these minerals and research techniques were discussed. Clay mineralogy was extensively dealt with especially from the point of view of the influence of clay minerals on the structure of soils and their chemical and physical properties. Papers were also included on clay migration and the specificity of olay minerals to certain types of soil-forming processes.

Particular interest was stimulated by the general sessions of the Congress when a number of invited lectures were given. The session on the World Soil Map has already been mentioned; other topics were: "The Dynamics of Water in Soils and Plants", by M. B. Russell; "New Methods of Research in Soil Science", by J. J. Fripiat; "Some Aspects of Nitrogen Metabolism in Soils", by G. W. Harmsen; "Tropical Soils", by G. Aubert; and a paper on "The Modern Dokuchaev Approach to Soil Classification" was read on behalf of I. P. Gerassimov, who was unfortunately unable to be present at the Congress.

Three symposia were held outside the scope of the Commissions: these dealt with the fertility of forest soils. the interaction of photosynthesis and mineral nutrition of plants, and metabolism of the primary assimilation of nutritive elements in the absorbent zone of roots.

For the energetic there was the choice of one of three tours, before or after the Congress. These proved extremely successful and were arranged to demonstrate the soils of south-east, east and north-east, and central and west Romania. For the not-so-energetic, profiles of all the major soil groups found in Romania were assembled in a magnificent display which was on view throughout the Congress. The All-Union Soil Science Society of the U.S.S.R. also organized an excursion from Moscow to Kherson, illustrating the soils of European Russia, and providing many interesting comparisons with similar soils on the plains of Romania.

The soil scientists of Romania have achieved a great deal in recent years, and the results of their hard work were well shown in the excellent presentation of the soil landscape of their country during the Congress and its tours. All who attended the eighth International Congress of Soil Science will want to congratulate their Romanian hosts on the smooth way in which the Congress was run and to wish them success in their future work.

E. M. Bridges

\section{USE OF FILMS IN RESEARCH AND TEACHING}

$A^{n}$ WORKIN( $x$ party, with Dr. W. L. Francis as chair man, formed by the Department of Scientific and Industrial Research in June 1960, following a meeting of thoso interested in scientific films from universities, industry and Government departments, has now reported on The Film in Scientific Research*.

* Department of Scientific and Industrial Research. The Film in Scientific Research: Report of a Working Party. Pp. vi +67 . (London: Department of Scientific and Industrial Research, 1963.)
The working party was to consider what is needed, in terms of information, research and development, in the field of scientific film and the appropriate functions of a central organization for scientific cinematography. It decided to limit its report mainly to the needs of scientific ciné-photography and photography, and to the uses of research film in research and in advanced teaching. An enquiry made for the working party by Mr. G. E. D. Bouler-Carter of Production Engineering, Ltd., indicated 